\title{
Pemenuhan Nutrisi Ternak dari Legum Indigofera dan Rumput Gajah Kerdil di Lokasi Demfarm Kabupaten Langkat Sumatera Utara
}

\section{Animal Nutritiont Fullfilment from Indigofera Legumes and Dwarf Elephant Grass in Demfarm Location, Langkat Regency, North Sumatra}

\author{
Solehudin $^{1, \mathrm{a}}$, Mubarak AS ${ }^{1}$, Syawal $\mathbf{M}^{1}$, Ginting SP${ }^{1}$ \\ ${ }^{1}$ Loka Penelitian Kambing Potong \\ PO. BOX 1 Galang 20585 Deliserdang Sumatera Utara \\ aemail: solehudintaher02@gmail.com
}

\begin{abstract}
Abstrak
Penanaman legum Indigofera dan rumput Gajah Kerdil merupakan teknologi pakan yang diterapkan dalam program UPSUS SIWAB di Sumatera Utara. Kajian bertujuan untuk mengevaluasi pemanfaatan legum Indigofera dan rumput Gajah Kerdil sebagai pakan sapi di Lokasi Demfarm yang terletak di Desa Gebang Kecamatan Pesiran Kabupaten Langkat. Metode kajian menggunakan sensus yang dilakukan pada 30 peternak sapi yang tergabung dalam kelompok ternak Sekata di lokasi tersebut. Data dianalisis secara deskriptif. Hasil kajian menunjukkan bahwa pemanfaatan legum Indigofera dan rumput Gajah Kerdil baru dapat memenuhi kebutuhan bahan kering, protein kasar dan TDN masing-masing 36,30 kg/h, 1,58 kg/h dan 20,07 kg/h. Persentase pemenuhan konsumsi bahan kering, protein kasar dan TDN masing-masing 5,82\%, 27,92\% dan 4,68\%. Dapat disimpulkan bahwa pemenuhan nutrisi dari legum Indigofera dan rumput Gajah Kerdil masih rendah sehingga perlu dikembangkan lagi untuk mendukung peningkatan performans ternak.dan keberhasilan program.
\end{abstract}

Kata Kunci: Nutrisi, Indigofera, Rumput Gajah Kerdil, Demfarm

\section{Abstract}

The planting of Indigofera legumes and Dwarf Elephant grass is a feed technology applied in the UPSUS SIWAB program in North Sumatra. The study was aimed to evaluate the utilization of Indigofera legumes and Dwarf Elephant grass as cattle feed at the Demfarm Location, located in Gebang Village, Pesiran District, Langkat Regency. The method used a census conducted on 30 livestock farmers as members of Sekata group at that location. Data were analyzed descriptively. The results showed that the utilization of Indigofera legumes and Dwarf Elephant grass fullfil the needs of dry matter, crude protein and TDN were $36.30 \mathrm{~kg} / \mathrm{d}, 1,58 \mathrm{~kg} / \mathrm{d}$ and $20.07 \mathrm{~kg} / \mathrm{d}$ respectively. The percentage fulfillment consumption of dry matter, crude protein and TDN were $5.82 \%, 27,92 \%$ and $4.68 \%$, respectively. It can be concluded that the fulfillment of nutrition from Indigofera legumes and Dwarf Elephant grass is still low so it needs to be developed to support improvement of animal performance and program success.

Key words: Nutrition, Indigofera, Dwarf Elephant, Demfarm

\section{Pendahuluan}

Pakan memiliki peranan yang sangat penting dalam menunjang keberhasilan sebuah usaha peternakan. Sekitar $60-70 \%$ usaha peternakan dipengaruhi oleh baik tidaknya pakan di samping genetik dan manajemen pemeliharaan. Sehingga pakan harus mendapat perhatian khusus agar keberhasilan usaha peternakan dapat terus berjalan secara berkesinambungan. Pada peternakan rakyat, hijauan biasanya dijadikan sebagai sumber pakan utama. Hijauan diperoleh dari lahanlahan yang ada di sekitar lingkungan tempat tinggal seperti sawah atau kebun berupa rumput, jerami, limbah-limbah hortikultura dan sebagainya.

UPSUS SIWAB (Upaya Khusus Sapi Induk Wajib Bunting) merupakan program Kementerian Pertanian dalam mendukung swasembada daging dengan cara meningkatkan populasi sapi baik melalui inseminasi buatan maupun kawin alam. Terdapat lima daerah di Indonesia yang 
dijadikan demfarm (percontohan) salah satunya di Kabupaten Langkat Sumatera Utara dengan target capaian utama program ini adalah meningkatnya populasi sapi. Jenis ternak dalam program ini adalah Sapi Peranakan Ongole (PO). Keberhasilan program ini didukung pula oleh kecukupan hijauan sebagai sumber nutrisi bagi ternak. Hijauan yang ditanam untuk mendukung kesuksesan program ini adalah legum Indigofera zollingeriana dan rumput Gajah Kerdil Pennisetum pupureum cv. Mott.

Indigofera zollingeriana merupakan legum yang mempunyai beberapa keunggulan. Kandungan protein Indigofera zollingeriana berkisar antara $21,54-26,22 \%$ dan dapat dikatakan bahwa Indigofera merupakan legum yang mempunyai kandungan protein tinggi dengan umur pemotongan terbaik 60 hari (Setyaningrum et al. 2018). Selain itu kandungan NDF Indigofera zollingeriana sebesar $36,72 \%$ sehingga dapat dijadikan pakan sumber serat (Sinar Tani, 2011). Hasil penelitian Nurhayu \& Pasambe, (2016) menyebutkan bahwa pemberian Indigofera pada sapi potong pada tingkat 40-60\% meningkatkan bobot badan dan menurunkan konversi pakan. Selain itu, penelitian lain menyebutkan penambahan legum Indigofera memberikan performans terbaik sapi induk PO yang ditambah dengan fermentasi jerami padi (Suherman et al., 2018). Salah satu kendala dari Indigofera adalah kurang disukai oleh ternak sehingga pemberiannya harus dicampur dengan rumput lapang atau jenis rumput yang diinteroduksi (Krisnan et al., 2012).

Rumput gajah kerdil Pennisetum purpureum $\mathrm{cv}$. Mott merupakan rumput yang memiliki kualitas unggul dengan kandungan Nitrogen 2-4\%. Kandungan protein kasar di atas $7 \%$ dan TDN mencapai $70 \%$ dan menurun seiring dengan naiknya umur tanaman (Budiman et al, 2012). Santia et al. (2017) menyebutkan umur pemotongan terbaik rumput gajah kerdil Pennisetum purpureum cv. Mott adalah 20 hari karena pada umur tersebut diperoleh rasio tertinggi antara daun dan batang. Lebih rinci lagi Sirait (2017) menjelaskan bahwa rumput gajah mini memiliki beberapa keunggulan dibandingkan dengan rumput gajah dalam hal pertumbuhan dan regrowth yang cepat dan dapat dimanfaatkan dalam sistem grazing dan cut and carry.

Kajian ini bertujuan untuk mengevaluasi pemenuhan kebutuhan nutrisi yang berasal dari legum Indigofera dan rumput gajah kerdil pada program UPSUS SIWAB di Kabupaten Langkat Sumatera Utara. Hasil kajian dapat digunakan untuk melihat sejauh mana peran hijauan dalam mensukseskan program tersebut.

\section{Materi dan Metode}

Kajian ini menggunakan metode sensus dengan cara wawancara langsung kepada seluruh peternak yang tergabung dalam kelompok peternak dalam demfarm tersebut. Pertanyaan terdiri dari jumlah ternak yang dimiliki dan pemberian hijauan (Indigofera dan rumput gajah kerdil) setiap hari. Ternak dibagi kedalam tiga jenis berdasarkan umur yaitu anak, muda dan dewasa tanpa membedakan jenis kelamin. Anak merupakan ternak yang berumur kurang dari 1 tahun, ternak muda adalah ternak yang berumur lebih dari 1 tahun tetapi kurang dari 2 tahun, sedangkan ternak dewasa merupakan ternak yang berumur di atas 2 tahun. Jumlah ternak masing-masing dikoneversikan ke dalam Satuan Ternak (ST) menggunakan metode Nell\&Rollingson (1974) dengan nilai 0,25 ST (anak), 0,6 (muda) dan 1,00 (dewasa). Hijauan (Indigofera dan rumput gajah kerdil) dihitung dengan pemberian rata-rata setiap hari. Semua data dari peternak direkap dalam tabel untuk dilanjutkan dengan perhitungan parameter.

Parameter yang diukur adalah konsumsi Bahan Kering (BK), konsumsi Protein Kasar (PK) dan konsumsi Total Digestible Nutrien (TDN). Konsumsi BK dihitung dengan cara mengalikan kandungan BK dalam masing-masing hijauan dengan jumlah hijauan yang dikonsumsi. Konsumsi PK dan TDN dihitung dengan cara mengalikan kandungan PK dan TDN dengan kandungan BK masing-masing dan jumlah hijauan yang dikonsumsi. Kebutuhan BK, PK dan TDN berturut-turut adalah $6,25 \mathrm{~kg} / \mathrm{ST}, 0,06 \mathrm{~kg} / \mathrm{ST}$ dan $4,3 \mathrm{~kg} / \mathrm{ST}$. Kandungan nutrisi hijauan tersaji dalam Tabel 1.

Data kemudian diolah dan dianalisis secara deskriptif dengan membandingkan data yang diperoleh dengan pustaka yang ada dan hasil penelitian yang telah dilakukan. 
Tabel 1. Kandungan nutrisi hijauan pakan

\begin{tabular}{lccc}
\hline \multirow{2}{*}{ Jenis Hijauan } & \multicolumn{3}{c}{ Kandungan Nutrisi (\%) } \\
\cline { 2 - 4 } & BK & PK & TDN* \\
\hline Indigofera zollingeriana & 21,97 & 24,17 & 52,40 \\
Pennisetum purpureum cv. Mott & 8,66 & 16,06 & 64,31 \\
\hline Sum
\end{tabular}

Sumber: Hasil Pengujian Laboratorium Pengujian Loka Penelitian Kambing Potong

*Perhitungan menggunakan rumus (Hartadi et al. 2005)

\section{Hasil dan Pembahasan}

Kajian mengenai pemenuhan nutrisi diawali dengan menghitung konsumsi Bahan Kering (BK), Protein Kasar (PK) dan Total Digestible Nutrien (TDN). Hasil perhitungan konsumsi BK, PK dan TDN disajikan pada Tabel 2.

Kebutuhan konsumsi Bahan Kering (BK) per hari untuk seluruh ternak adalah $623,75 \mathrm{~kg}$. Pemenuhan konsumsi BK dari Indigofera dan rumput gajah kerdil adalah 36,3 $\mathrm{kg}$ atau 5,82\% dari seluruh kebutuhan BK. Persentase pemenuhan BK tertinggi dipenuhi oleh ternak muda sebesar 16,12\%, anak sebesar $10,56 \%$ dan dewasa $3,72 \%$.
Pemenuhan konsumsi BK dari Indigofera lebih tinggi daripada rumput gajah kerdil karena kandungan BK Indigofera lebih tinggi daripada rumput gajah kerdil walaupun dengan konsumsi hijauan segar yang hampir sama. Bahan Kering merupakan keseluruhan nutrisi pakan setelah dikurangi kandungan airnya. Konsumsi bahan kering berkaitan dengan kapasitas fisik lambung dan saluran pencernaan secra keseluruhan (Parakkasi, 1999). Apabila ternak kekurangan bahan kering, maka ternak akan merasa lapar karena kapasitas lambungnya tidak terisi secara maksimal. Sapi mengkonsumsi bahan kering $3-4 \%$ dari bobot tubuhnya.

Tabel 2. Konsumsi BK, PK dan TDN

\begin{tabular}{lcccc}
\hline \multirow{2}{*}{ Uraian } & \multicolumn{3}{c}{ Jenis Ternak } & \multirow{2}{*}{ Jumlah } \\
\cline { 2 - 4 } & Anak & Muda & Dewasa & \\
\hline Jumlah Ternak (ekor) & 44 & 14 & 78 & 140 \\
Standar Ternak dalam ST & 0,25 & 0,6 & 1,00 & \\
Jumlah Ternak dalam ST & 11 & 10,80 & 78,00 & 99,80 \\
Kebutuhan BK per hari (kg) & 68,75 & 67,50 & 487,50 & 623,75 \\
Kebutuhan PK per hari (kg) & 0,66 & 0,65 & 4,68 & 5,99 \\
Kebutuhan TDN per hari (kg) & 47,30 & 46,44 & 335,40 & 429,14 \\
Konsumsi Hijauan per hari & & & & \\
$\quad$ a. Indigofera (kg) & 25,00 & 37,50 & 62,50 & 125,00 \\
$\quad$ b. Rumput gajah kerdil (kg) & 20,40 & 30,60 & 51,00 & 102,00 \\
Konsumsi BK per hari & & & & \\
$\quad$ a. Indigofera (kg) & 5,49 & 8,24 & 13,73 & 27,47 \\
$\quad$ b. Rumput gajah kerdil (kg) & 1,77 & 2,65 & 4,42 & 8,83 \\
Konsumsi PK per hari & & & & \\
$\quad$ a. Indigofera (kg) & 0,29 & 0,44 & 0,73 & 1,46 \\
$\quad$ b. Rumput gajah kerdil (kg) & 0,02 & 0,04 & 0,06 & 0,12 \\
Konsumsi TDN per hari & & & & \\
$\quad$ a. Indigofera (kg) & 2,88 & 4,32 & 7,20 & 14,39 \\
$\quad$ b. Rumput gajah kerdil (kg) & 1,14 & 1,70 & 2,84 & 5,68 \\
\hline
\end{tabular}

Kebutuhan konsumsi Protein Kasar (PK) per hari untuk seluruh ternak adalah $5,99 \mathrm{~kg}$. Pemenuhan konsumsi PK dari Indigofera dan rumput gajah kerdil adalah $1,58 \mathrm{~kg}$ atau 27,92\% dari seluruh kebutuhan konsumsi PK. Pemenuhan konsumsi PK tertinggi diperoleh oleh ternak muda sebesar $73,85 \%$, anak sebesar 46,97\% dan dewasa 16,88\%. Walaupun dengan konsumsi BK hanya 5,82\% tetapi pemenuhan konsumsi PK dapat mencapai di atas $15 \%$ bahkan lebih dari 50\% untuk ternak muda. Hal ini dikarenakan daun 
Indigofera mengandung PK yang tinggi. Tingginya pemenuhan konsumsi PK yang melebihi konsumsi BK dapat dikatakan bahwa legum Indigofera berpeluang besar dijadikan pakan sumber protein untuk sapi. Protein kasar merupakan kandungan $\mathrm{N}$ dalam bahan pakan dikalikan 6,25 $(\mathrm{Nx} 6,25)$. Kekurangan protein dapat menghambat pertumbuhan karena protein berfungsi untuk memperbaiki jaringan tubuh, pertumbuhan jaringan baru dan sumber energi (Anggorodi, 1994).

Kebutuhan konsumsi TDN per hari untuk seluruh ternak adalah 429,14 $\mathrm{kg}$. Pemenuhan konsumsi TDN dari Indigofera dan rumput gajah kerdil adalah $20,07 \mathrm{~kg}$ atau 4,68\% dari seluruh kebutuhan konsumsi TDN. Persentase pemenuhan konsumsi TDN untuk anak, muda dan dewasa berturut-turut adalah $8,50 \%, 12,96 \%$ dan 2,99\%. Kandungan TDN dari rumput gajah kerdil lebih tinggi daripada Indigofera tetapi kandungan BK rumput gajah kerdil lebih rendah daripada Indigofera sehingga dengan konsumsi hijauan segar yang hampir sama tidak menyebabkan konsumsi TDN meningkat. TDN merupakan keseluruhan energi yang terkandung dalam bahan pakan. Ternak memanfaatkan energi untuk pertumbuhan dan produksi setelah terpenuhinya kebutuhan hidup pokok. Menurut Tillman et.al (1991) kekurangan energi dapat mengakibatkan terhambatnya pertambahan bobbot badan, penurunan bobot badan dan terganggunya produksi. Jika kekurangan energi berlangsung dapat menyebabkan kematian.

\section{Kesimpulan}

Pemenuhan nutrisi sapi di lokasi Demfarm Kabupaten Langkat Sumatera Utara yang berasal dari legum Indigofera dan rumput gajah kerdil untuk Bahan Kering (BK), Protein Kasar (PK) dan TDN masing-masing berturutturut adalah $5,82 \%, 27,92 \%$ dan $4,68 \%$. Berdasarkan konsumsi bahan keringnya dapat dikatakan bahwa pemenuhan nutrisi dari hijauan tersebut masih rendah sehingga perlu ditingkatkan konsumsi segarnya. Konsumsi segar dapat ditingkatkan apabila hijauan tersebut tersedia dalam jumlah yang memadai sehingga harus dikembangkan lagi.

\section{Daftar Pustaka}

Angggordi R. 1994. Ilmu Makanan Ternak Umum. Jakarta, Indonesia:PT. Gramedia Pustaka Utama.

Budiman, Soetrisno, Budi SPS, Indrianto A. 2012. Morphological Characteristic, Productivity and Quality of Three Napier Grass (Pennisetum purpureum Schum) Cultivars Harvested at Different Age. Yogyakarta, Indonesia: Gajah Mada University Press.

Hartadi H, Reksohadiprodjo S, Tillman AD. 2005. Tabel Komposisi Pakan untuk Indonesia. Yogyakarta, Indonesia: Gajah Mada University Press.

Krisnan R, Sirait J, Tarigan A, Simanihuruk K. 2012. Indigofera sebagai Pakan Ternak. IAARD Press, Pusat Penelitian dan Pengembangan Peternkan Badan Litbang Pertanian.

Nell AJ, Rollington DHL. 1974. The Requirement and Availability of Livestock Feed in Indonesia. Jakarta, Indonesia: Working Paper.

Nurhayu A, Pasambe D. 2016. Indigoefera sebagai Substitusi Hijauan Pakan Sapi Potong di Kabupaten Bulukumba Sulawesi Selatan. Seminar Nasional Peternakan 2 Fakultas Peternakan Universitas Hasanuddin.

Parakkasi A. 1999. Ilmu Nutrisi dan makanan Ternak Ruminansia. Jakarta, Indonesia: Universitas Indonesia.

Santia, Anis SD, Kaunang CL. 2017. Pengaruh Tinggi dan Jarak Waktu Pemotongan Rumput Gajah Dwarf (Pennisetum purpureum cv. Mott) terhadap Pertumbuhan Vegetatif dan Produksi Bahan Kering. Jurnal Zootek (16):116122.

https://doi.org/10.35792/zot.37.1.2017.14 354

Setyaningrum E, Kaca IN, Suwitari NKE. 2018. Pengaruh Umur Pemotongan terhadap Kualitas Nutrisi Tanaman Indigofera (Indigofera $s p$ ). Gema Agro 23 (1):59-62.

https://ejournal.warmadewa.ac.id/index.p $\mathrm{hp} /$ gemaagro

DOI:10.22225/ga.23.1.660.59-62

Sinar Tani. 2011. Tanaman Indigofera untuk Trenak Kambing. Ed 14-20 Desember 
2011 No. 3435 Tahun XLII Badan Litbang Kementerian Pertanian.

Sirait J. 2017. Rumput Gajah Mini (Pennisetum purpureum cv. Mott) sebagai Bahan Pakan Ruminansia. Wartazoa (27):167-176.

http://repository.pertanian.go.id/handle $/ 123456789 / 4517$

Suherman A, Mahmud Y, Hikmana E, Ambasari W, Hernaman I, Yuhani H, Salim R. 2018. Performa Sapi Peranakan
Ongole Betina yang Diberi Ransum Berbasis Jerami Padi Fermentasi yang Mengandung Indigofera zollingeriana. Sains Peternakan 16(2): 40-44. http://dx.doi.org/10.20961/sainspet.v16i2. 19756

Tillman AD, Reksohadiprodjo S, Prawirokusumo S, Hartadi H, Lebdosukodjo S. 1991. Ilmu Makanan Ternak Dasar. Yogyakarta, Indonesia: Gadjah Mada University Press. 